\title{
Sunlight inactivation of fecal indicator bacteria in open-water unit process treatment wetlands: Modeling endogenous and exogenous inactivation rates
}

\author{
Mi T. Nguyen a, b, Justin T. Jasper ${ }^{\text {a, b }}$, Alexandria B. Boehm ${ }^{\text {a, c }}$, Kara L. Nelson ${ }^{\text {a, b, * }}$ \\ a Engineering Research Center for Re-Inventing the Nation's Urban Water Infrastructure (ReNUWIt), USA \\ b Department of Civil and Environmental Engineering, University of California, Berkeley, CA 94720-1710, USA \\ ${ }^{\mathrm{c}}$ Department of Civil and Environmental Engineering, Stanford University Stanford, CA 94305, USA
}

\section{A R T I C L E I N F O}

\section{Article history:}

Received 11 March 2015

Received in revised form

14 June 2015

Accepted 25 June 2015

Available online 30 June 2015

\section{Keywords:}

Disinfection

Wastewater treatment

Constructed wetlands

Pathogens

\begin{abstract}
A B S T R A C T
A pilot-scale open-water unit process wetland was monitored for one year and found to be effective in enhancing sunlight inactivation of fecal indicator bacteria (FIB). The removal of Escherichia coli and enterococci in the open-water wetland receiving non-disinfected secondary municipal wastewater reached 3 logs and 2 logs in summer time, respectively. Pigmented enterococci were shown to be significantly more resistant to sunlight inactivation than non-pigmented enterococci. A model was developed to predict the inactivation of $E$. coli, and pigmented and non-pigmented enterococci that accounts for endogenous and exogenous sunlight inactivation mechanisms and dark processes. Endogenous inactivation rates were modeled using the sum of UVA and UVB irradiance. Exogenous inactivation was only significant for enterococci, and was modeled as a function of steady-state singlet oxygen concentration. The rate constants were determined from lab experiments and an empirical correction factor was used to account for differences between lab and field conditions. The model was used to predict removal rate constants for FIB in the pilot-scale wetland; considering the variability of the monitoring data, there was general agreement between the modeled values and those determined from measurements. Using the model, we estimate that open-water wetlands at $40^{\circ}$ latitude with practical sizes can achieve 3-log (99.9\%) removal of $E$. coli and non-pigmented enterococci throughout the year [5.5 ha and 7.0 ha per million gallons of wastewater effluent per day (MGD), respectively]. Differences in sunlight inactivation rates observed between pigmented and non-pigmented enterococci, as well as between lab-cultured and indigenous wastewater bacteria highlight the challenges of using FIB as model organisms for actual pathogens in natural sunlit environments.
\end{abstract}

(c) 2015 Elsevier Ltd. All rights reserved.

\section{Introduction}

Constructed wetlands dominated by emergent macrophytes are capable of providing modest removal of fecal indicator bacteria (FIB) (e.g., up to $80 \%$ removal of total and fecal coliforms and $99 \%$ removal of fecal streptococci) via cell die-off, attachment-sedimentation, and predation processes (Kadlec and Wallace, 2009). Sunlight inactivation, an important mode of disinfection in waste stabilization ponds (Davies-Colley et al., 1997) and other sunlit waters (Boehm et al., 2009; McGuigan et al., 2012), is usually

\footnotetext{
* Corresponding author. Department of Civil and Environmental Engineering, University of California, Berkeley, CA 94720-1710, USA
}

E-mail address: karanelson@berkeley.edu (K.L. Nelson). insignificant in vegetated wetlands due to shading by emergent macrophytes and floating vegetation. Unit process wetlands, consisting of individual cells that are designed to treat specific contaminants, can promote sunlight inactivation in shallow, openwater cells (Horne and Fleming-Singer, 2005; Jasper et al., 2013).

Three mechanisms of sunlight inactivation can affect bacteria in shallow, open-water wetlands: direct and indirect endogenous mechanisms and indirect exogenous mechanism (Davies-Colley et al., 1999; Silverman et al., 2013). Direct endogenous inactivation is caused by damage to bacterial components that absorb solar irradiation (e.g., nucleic acids) (Jagger, 1985). Indirect endogenous inactivation occurs when solar irradiation is absorbed by endogenous photosensitizers (e.g., NADH/NADPH, flavins, porphyrins) to form reactive intermediates which can damage other components 
of the bacterium (Cunningham et al., 1985). Exogenous inactivation occurs when photosensitizers in the water absorb solar irradiation and produce exogenous reactive intermediates [e.g., singlet oxygen $\left({ }^{1} \mathrm{O}_{2}\right)$, hydrogen peroxide $\left(\mathrm{H}_{2} \mathrm{O}_{2}\right)$, superoxide $\left(\mathrm{O}_{2}{ }^{-}\right)$, and hydroxyl radical $(\bullet \mathrm{OH})$ ] (Cooper et al., 1989). The contribution of each mechanism to sunlight inactivation is expected to vary for different bacteria, depending on their susceptibility to each mechanism and the water quality conditions. Despite the growing understanding of sunlight inactivation mechanisms of bacteria, modeling approaches have not yet been developed that account separately for endogenous and exogenous inactivation mechanisms. Two recent papers presented approaches for modeling the endogenous and exogenous sunlight inactivation of viruses (Mattle et al., 2015; Silverman et al., 2015); this paper builds upon the approach we developed in Silverman et al.

The goals of this research were to evaluate the removal of indigenous FIB in a pilot-scale open-water wetland receiving nitrified, undisinfected wastewater, and to develop a predictive model for FIB removal that accounts for endogenous and exogenous inactivation mechanisms. Inactivation rate constants were determined from lab experiments and an empirical correction factor was used to account for differences between lab and field conditions. The model was evaluated using one year of monitoring data from the pilot-scale open-water wetland. The improved understanding of mechanisms and the model can be used to optimize the design of unit process wetlands for FIB removal. The modeling approach can be applied to other sunlit waters, where sunlight inactivation also plays a key role in FIB removal.

\section{Materials and methods}

The research consisted of six specific tasks. Tasks one through four consisted of experiments, which are summarized in Table 1 (the task numbers are indicated). The tasks were: (1) monitoring the removal of indigenous wastewater Escherichia coli and enterococci in the open-water wetland for one year; (2) in-situ batch experiments to measure inactivation rates of indigenous FIB in the field under controlled conditions (e.g., simplified hydraulics and known initial concentration); (3) lab experiments to determine inactivation rates for endogenous and exogenous mechanisms of lab-cultured E. coli and enterococcal isolates with simulated sunlight; (4) lab comparison of sunlight inactivation rates of labcultured and indigenous wastewater FIB collected from the wetland influent; (5) development of the model to predict sunlight inactivation rates of FIB in the wetland; and (6) comparison of modeling results with the monitoring data. A detailed description of each task is provided in the sections below.

We used $k_{o b s}$ terms for experimentally measured inactivation rates, and $k_{\text {tot }}$ terms for modeled inactivation rates, which are calculated as the sum of endogenous inactivation rate $k_{\text {endo, }}$ exogenous inactivation rate $k_{\text {exo }}$, and dark removal rate $k_{\text {dark }}$ (see more details in Section 2.3). The superscript $L$ is used to denote measured and modeled inactivation rates in the laboratory, $B$ is for the in-situ batch reactors, and $W$ is for the wetland.

\subsection{Experiments at the pilot-scale open-water wetland}

\subsubsection{Monitoring concentrations of indigenous FIB in the open- water wetland (task 1)}

Concentrations of $E$. coli and enterococci in a pilot-scale openwater wetland in Discovery Bay, CA $\left(37^{\circ} 54^{\prime} \mathrm{N}, 121^{\circ} 36^{\prime} \mathrm{W}\right)$ were monitored throughout the year. The $400 \mathrm{~m}^{2}$ open-water cell was approximately $20 \mathrm{~cm}$ deep and received approximately $86 \mathrm{~m}^{3} \mathrm{~d}^{-1}$ of nitrified, undisinfected wastewater (hereafter referred to as wastewater) from the adjacent oxidation ditch at the Discovery Bay wastewater treatment plant [servicing 12,560 people at the time of the 2011 census (Demographics of The Town of Discovery Bay, 2011)]. The wetland contained three baffles to promote plug-flow hydraulic conditions, and was lined with concrete and geotextile fabric to prevent the growth of emergent macrophytes. A 2-10-cm deep, porous, diffuse biomat composed of algae (mainly diatoms), associated heterotrophic microbes, and detritus accumulated on the wetland bottom (Jasper et al., 2014a). During the day, photosynthesis at the biomat surface increased the concentration of dissolved oxygen throughout the water column.

Grab samples were collected from one to seven times per month at different locations in the wetland (i.e., inlet, outlet, and turns 1,2 , and 3) from January to December 2012. A photograph of the openwater wetland with sampling locations can be found in Supplementary Information (SI), Fig. S1. During September, part of October, and November 2012 duckweed covered the entire water surface of the wetland and sunlight exposure was minimal. Samples were collected in sterile bottles and stored on ice for less than $4 \mathrm{~h}$ prior to analysis. The concentrations (MPN/100 mL) of E. coli and enterococci were determined using Colilert and Enterolert defined substrate assays implemented in 97 well Quanti-Trays following vendor instructions (IDEXX, Westbook, MN).

$\mathrm{pH}$, dissolved oxygen (DO), conductivity, and temperature measurements of the wetland water were recorded each sampling event using Manta multi-probes (Eureka Environmental) located at the inlet and outlet of the cell (Fig. S2). Dissolved organic carbon (DOC) concentrations (TOC-VSH, Shimadzu) and UV-VIS absorbance spectra (280-700 nm; pathlength $0.01 \mathrm{~m}$; Lambda 35, Perkin-Elmer) were also measured (Fig. S3).

\subsubsection{Experiments with in-situ batch reactors at the open-water wetland (task 2)}

Acrylic tanks (open on top) containing biomat collected from

Table 1

Summary of experiments conducted in this research.

\begin{tabular}{|c|c|c|}
\hline Conditions & Experiments & Objectives \\
\hline $\begin{array}{l}\text { Pilot-scale open-water wetland } \\
\quad \text { (task 1) }\end{array}$ & $\begin{array}{l}\text { Monitoring concentrations of indigenous wastewater FIB } \\
\text { for one year }\end{array}$ & $\begin{array}{l}\text { - Characterize performance of pilot wetland } \\
\text { - Determine removal rate constants of indigenous FIB }\left(k_{o b s}^{W}\right) \text { in the pilot } \\
\text { wetland }\end{array}$ \\
\hline In-situ batch reactor (task 2) & $\begin{array}{l}\text { Dark reactors } \\
\text { Light reactors }\end{array}$ & $\begin{array}{l}\text { - Measure dark removal rate constant of indigenous FIB }\left(k_{d a r k}^{B}\right) \\
\text { - Measure total removal rate constant of indigenous FIB }\left(k_{o b s}^{B}\right)\end{array}$ \\
\hline Laboratory & $\begin{array}{l}\text { Lab-cultured FIB in clear water (task } 3 \text { ) } \\
\text { Lab-cultured FIB in wetland water (task } 3 \text { ) } \\
\text { Lab-cultured FIB vs. Indigenous wastewater FIB in clear } \\
\text { water (task 4) }\end{array}$ & $\begin{array}{l}\text { - Characterize importance of endogenous mechanisms } \\
\text { - Determine endogenous inactivation rate constant }\left(k_{e n d o}^{L}\right) \\
\text { - Characterize importance of exogenous mechanism } \\
\text { - Determine exogenous inactivation rate constants }\left(k_{e x o}^{L} \text { and } k_{2}\right) \\
\text { - Measure the difference in susceptibility to sunlight inactivation of FIB from } \\
\text { these two sources }\end{array}$ \\
\hline
\end{tabular}


the biomat layer at turn 2 in the open-water wetland and wastewater from the wetland influent were used for in-situ (e.g. tanks were immersed in the wetland) batch experiments. The wetland influent (rather than effluent) was used to ensure high enough initial concentrations of the indigenous indicator bacteria in the batch reactors. A biomat volume of $4.75 \mathrm{~L}$ was mixed with $19 \mathrm{~L}$ of wastewater, resulting in $20 \mathrm{~cm}$ total depth with $5 \mathrm{~cm}$ of sediment after the sediment settled down in $\sim 10 \mathrm{~min}$. A separate experiment was conducted to verify that the inactivation rates in tanks were similar for $100 \%$ influent versus a 50:50 mixture of wetland influent and effluent (Fig. S6), confirming that the wetland influent could be used to represent water in the whole wetland. Aluminum foil was used to cover the outside of the reactors for dark controls. One dark control was included in each experiment. A single biomat-free control that contained only wastewater was also included in one experiment. Reactors containing biomat and exposed to sunlight were duplicated in each experiment. Grab samples were collected at 8:00 and 17:00 (local time) on two consecutive days and analyzed for $E$. coli and enterococci concentrations using IDEXX. Experiments were conducted in August and October 2012, and June 2014. Due to the small percentage of water that was estimated to be lost via evaporation ( $7.3 \pm 1.1 \%$; Jasper et al., 2014a), no water was added during the course of the in-situ batch experiments.

The observed, first-order inactivation rate constants of indigenous wastewater bacteria in the in-situ batch reactors were calculated from linear regression of $\ln \left(C_{t} / C_{0}\right)$ versus time $\left(k_{o b s}^{B}, \mathrm{~h}^{-1}\right)$. The reported data are mean values of duplicate samples \pm one standard error.

\subsubsection{Isolation, pigmentation test, and speciation for indigenous wastewater enterococci (tasks 1 and 2)}

The pigmentation test was conducted with samples collected from the wetland at three locations (inlet, turn 2, and outlet) on 3 days when the wetland was covered by duckweed, and 4 other days in October 2012 when the water was exposed to sunlight. For insitu batch reactors, pigmentation tests were conducted for samples that were collected from dark controls and reactors exposed to sunlight during two experiments in October 2012. Indigenous enterococci were isolated from each positive well in the Enterolert Quantitrays and tested for yellow pigmentation (Facklam and Collins, 1989) (see SI for more details). A total of $\sim 3200$ isolates was collected and tested for pigmentation. The relative abundance (\%) of pigmented and non-pigmented enterococci was calculated based on the fraction of pigmented or non-pigmented isolates out of the total number of isolates. To determine the concentration of pigmented or non-pigmented enterococci in any sample, the total concentration was multiplied by the relative abundance (represented as a fraction) for the same sample type (same location for the wetland samples, and same treatment time for the batch reactors). The relative abundance values in samples collected in October were used to determine concentrations of pigmented and non-pigmented enterococci in samples collected from the openwater wetland and in-situ reactors on other dates. This estimation was conducted with an assumption that the relative abundance values would change similarly as a function of treatment time in any season. Eleven wetland water isolates (4 pigmented, 7 non-pigmented) were randomly chosen for 16S rRNA sequencing at the UC Berkeley DNA sequencing facility to be confirmed as enterococci. Details of $16 \mathrm{~S}$ rRNA sequencing of these isolates are presented in SI. 10 out of 11 of the chosen candidate isolates were confirmed as enterococci and one was identified as Lactococcus spp. One pigmented and one non-pigmented enterococcal isolate were chosen for inactivation experiments under simulated sunlight (described below in Task 3).

\subsubsection{Collecting indigenous FIB from wastewater from the wetland influent (task 4)}

Four pre-sterilized positively charged NanoCeram VS2.5-5 cartridge filters (Argonide Corporation, Sanford, FL) were used to collect indigenous wastewater FIB from approximately $510 \mathrm{~L}$ (per filter) of the wetland influent. Sample collection steps were conducted following USEPA's instructions for concentrating waterborne viruses using positively-charged cartridge filters (Fout et al. 2001), and described in detail in SI. Briefly, the bacteria trapped in the cartridge filters were eluted using Beef Extract (3\% Beef Extract, 3\% Tween $80,0.3 \mathrm{M} \mathrm{NaCl}$, pH 9.0), followed by sequential steps of centrifugation and washing the pellets with sterile phosphatebuffered saline (PBS, $5 \mathrm{mM} \mathrm{NaH} \mathrm{PO}_{4}, 18 \mathrm{mM} \mathrm{Na}_{2} \mathrm{HPO}_{4}, 145 \mathrm{mM}$ $\mathrm{NaCl}, \mathrm{pH} 7.5$ ) to clean the bacterial cells. After the collection and purification steps, the concentrations of indigenous E. coli and enterococci were $3 \times 10^{7}$ and $1 \times 10^{6}$ most probable number $(\mathrm{MPN}) / 100 \mathrm{~mL}$, respectively; their initial concentrations in the wastewater were $3 \times 10^{4}$ and $1 \times 10^{3} \mathrm{MPN} / 100 \mathrm{~mL}$, respectively. The recovery of the bacteria after the collection and purification procedure was approximately $2 \%$.

\subsection{Lab experiments (tasks 3 and 4)}

\subsubsection{Growing and harvesting lab-cultured bacteria}

The five lab-cultured bacteria used in this study were $E$. coli NCM 4236, Enterococcus faecalis ATCC 19433, Enterococcus casseliflavus ATCC 25788, and pigmented and non-pigmented enterococcal isolates from the wetland (Table S1). Lab-cultured bacteria were stored as glycerol stocks at $-80^{\circ} \mathrm{C}$. Broth cultures were prepared fresh daily by inoculating the glycerol stocks in tryptic soy (BD, Difco 211825) and brain heart infusion (BD, Difco 237500) broths for $E$. coli and enterococci, respectively. Broth cultures were then incubated at $37{ }^{\circ} \mathrm{C}$ for $24 \mathrm{~h}$ for the bacteria to reach stationary phase. Cells were pelleted by centrifuging at $6800 \times \mathrm{g}$ for $3 \mathrm{~min}$, then washed and resuspended with PBS. The initial concentrations of bacteria were $\sim 10^{7}$ colony forming units (CFU)/mL in sunlight inactivation experiments under simulated sunlight.

\subsubsection{Inactivation experiments under simulated sunlight}

Bacteria were added to clear water $\left(20 \mathrm{mM} \mathrm{NaH}_{2} \mathrm{PO}_{4}, 10 \mathrm{mM}\right.$ $\mathrm{NaCl}, \mathrm{pH}$ adjusted to 7.5) or wetland water (collected at the outlet of the open-water wetland at Discovery Bay, $\mathrm{pH}$ adjusted to 7.5). Experiments were conducted in uncovered, 5-cm deep, black-painted, glass beakers, which were stirred and maintained at $20^{\circ} \mathrm{C}$. The beakers were irradiated using an ozone-free $1000 \mathrm{~W}$ Xe arc lamp housed in a solar simulator (Oriel, model number 91194; Newport; Irvine, CA) fitted with a 1.5:G:A global air mass filter (Newport, part number 81388) and an atmospheric attenuation filter (Newport, part number 81017) to mimic the solar spectrum at summer noon at Discovery Bay. Some experiments were also conducted with a UVB-blocking filter (see Fig. S7 for solar simulator spectra). Dark controls were maintained under the same conditions as light samples, but covered with aluminum foil. Subsamples were collected periodically for enumeration of $E$. coli or enterococci using spread plate method. Selective media mTEC agar (BD, Difco, 214884) and mEnterococcus agar (BD, Difco, 274620) were used for enumeration of $E$. coli and enterococci, respectively, to avoid interference of other microorganisms in wetland water. Experiments were conducted in duplicate reactors on the same day using the same bacterial seed culture.

The observed, first-order inactivation rate constants of bacteria in lab experiments were calculated from linear regression of graphs of $\ln \left(C_{t} / C_{0}\right)$ verses either time $\left(k_{o b s}^{L}, \mathrm{~h}^{-1}\right)$ or photon fluence $\left(k_{o b s, p h o t o n}^{L}, \mathrm{~m}^{2} \mathrm{Ei}^{-1}\right) . k_{o b s, p h o t o n}^{L}$ values were $k_{o b s}^{L}$ values after correcting for light screening. The observed inactivation rates of 
duplicate reactors were averaged and are reported as the mean values \pm one standard error.

\subsection{Modeling inactivation of FIB in in-situ batch reactors and the open-water wetland (task 5)}

The modeled inactivation rate constants in in-situ batch reactors and the open-water wetland $\left(k_{t o t}^{i}, \mathrm{i}=\mathrm{B}\right.$ for in-situ batch reactors or $\mathrm{W}$ for open-water wetland) were estimated as the sum of the rate constants of all possible inactivation processes, including: sunlight inactivation (endogenous and exogenous mechanisms, $k_{\text {endo }}^{i}$ and $\left.k_{e x o}^{i}\right)$, and dark inactivation $\left(k_{\text {dark }}^{i}\right)$ :

$k_{\text {tot }}^{i}=k_{\text {endo }}^{i}+k_{\text {exo }}^{i}+k_{\text {dark }}^{i}$

$k_{\text {dark }}^{W}$ values of the FIB were assumed to be equal to their $k_{\text {dark }}^{B}$ values from dark controls in in-situ batch experiments. The water column was assumed to be equal to $20 \mathrm{~cm}$ throughout the whole wetland, and the water was well-mixed across this depth. As in previous research, $k_{\text {endo }}^{i}$ and $k_{\text {exo }}^{i}$ values of the FIB were multiplied by $15 / 20$ to account for the shading effect of the $5-\mathrm{cm}$ thick biomat layer on the bottom of the wetland (Jasper and Sedlak, 2013; Silverman et al., 2015).

The main steps for modeling the inactivation rate constants for indigenous FIB in the pilot-scale wetland, $k_{\text {endo }}^{W}$ and $k_{\text {exo }}^{W}$, are summarized here with further description in sections below.

- Rate constants determined from lab experiments $\left(k_{\text {endo }}^{L}\right.$ and $\left.k_{\text {exo }}^{L}\right)$ were adjusted to the field conditions of the pilot-scale wetland to account for differences in sunlight spectra, water column absorbance, and steady-state singlet oxygen concentrations.

- A correction factor $(r)$ was used to correct for differences between lab-cultured and indigenous FIB, as well as other discrepancies between lab and wetland conditions (e.g., diurnal fluctuation of $\mathrm{pH}, \mathrm{DO}$, and temperature).

\subsubsection{Determining solar irradiance}

Solar irradiance was measured in the field using a spectroradiometer with a cosine detector (EPP2000-HR, CR2; StellarNet Inc.). These data were used for modeling the conditions in the in-situ batch reactors on two cloudy days in October 2012. For modeling the sunlight conditions on all other (sunny) days, solar irradiance was predicted for each hour and averaged for $24 \mathrm{~h}$ using the Simple Model of the Atmospheric Radiative Transfer of Sunshine (SMARTS) (Gueymard, 2005) (Fig. S4). To model inactivation in the wetland, irradiance values were predicted for the 21 st day of each month using SMARTS. Solar irradiance at different depths in the water column was estimated as previously described (see SI for more details, Fig. S5) (Nguyen et al., 2014).

\subsubsection{Calculating $k_{\text {endo }}^{B}$}

Values of $k_{\text {endo }}^{B}\left(\mathrm{~d}^{-1}\right)$ were estimated based on the inactivation rates of lab-cultured bacteria in clear water without photosensitizers $\left(k_{\text {endo }}^{L}, \mathrm{~h}^{-1}\right)$ under full spectrum simulated sunlight. Due to the lack of photoaction spectra for the bacteria, it was assumed that the inactivation rates scaled linearly with total UVA and UVB irradiance (280-400 nm), as these are the wavelengths responsible for the majority of endogenous inactivation of $E$. coli and enterococci (Davies-Colley et al., 1997; Kadir and Nelson, 2014; Sinton et al., 2002). This approach is supported by previous research demonstrating that sunlight inactivation rates of $E$. coli were a function of fluence (the product of irradiance and time; Berney et al., 2006b), although it should be noted that significant shifts in the proportion of UVA and UVB light may alter this dependence on fluence (Nguyen et al., 2014; Silverman et al., 2015).

$$
k_{\text {endo }}^{B}=24 \times k_{\text {endo }}^{L} \times \frac{\sum_{\lambda=280}^{400}\left\langle E_{0}^{\text {sun }}(z, \lambda)\right\rangle_{z}}{\sum_{\lambda=280}^{400}\left\langle E_{0}^{\text {sim }}(z, \lambda)\right\rangle_{z}}
$$

Values for $k_{\text {endo }}^{L}\left(\mathrm{~h}^{-1}\right)$ are the inactivation rate constants determined from experiments of lab-cultured $E$. coli, and pigmented and non-pigmented enterococcal isolates in clear water with fullspectrum simulated sunlight. Equation (2) was multiplied by $24 \mathrm{~h} / \mathrm{d}$ to convert units to $\mathrm{d}^{-1} \cdot \sum_{\lambda=280}^{400}\left\langle E_{0}^{\text {sim }}(z, \lambda)\right\rangle_{z}$ is the sum of depth-averaged scalar simulated light irradiance from 280 to $400 \mathrm{~nm}$ in the clear water column of the reactor, and $\sum_{\lambda=280}^{400}\left\langle E_{0}^{\operatorname{sun}}(z, \lambda)\right\rangle_{z}$ is the sum of $24 \mathrm{~h}$-averaged, depth-averaged scalar solar irradiance in the wetland water column; additional details of the light irradiance calculations are presented in SI and Table S2.

\subsubsection{Calculating $k_{\text {exo }}^{B}$}

Exogenous inactivation rates were only calculated for enterococci due to the resistance of the lab strain $E$. coli to the exogenous mechanism (see Results). $k_{\text {exo }}^{B}$ values of indigenous enterococci in in-situ batch reactors were calculated as a function of the steadystate concentration of ${ }^{1} \mathrm{O}_{2}$ because it was previously found to be an important reactive intermediate contributing to the inactivation of MS2 bacteriophage (Kohn and Nelson, 2007), and is likely involved in the exogenous inactivation of Ent. faecalis (Kadir and Nelson, 2014). The impact of $\bullet \mathrm{OH}$, which is mainly produced by photolysis of $\mathrm{NO}_{3}{ }^{-}$in the wetland $\left(\left[\mathrm{NO}_{3}^{-}\right]_{\text {influent }}=21 \mathrm{mg} \mathrm{N} \mathrm{L}^{-1}\right)$ on the exogenous inactivation of the FIB was assumed to be negligible because there was no observed enhancement in sunlight inactivation of lab-cultured E. coli and Ent. faecalis in the presence of added $\mathrm{NO}_{3}{ }^{-}\left(0,20\right.$ and $\left.100 \mathrm{mg} \mathrm{N} \mathrm{L}^{-1}\right)$ (data not shown). It is likely that other reactive intermediates are involved in exogenous inactivation, but given the incomplete knowledge it was assumed that all exogenous processes scale with the steady-state concentration of ${ }^{1} \mathrm{O}_{2}$. Thus, inactivation by the exogenous mechanism was modeled as a pseudo, first-order reaction with the rate constant $k_{\text {exo }}^{B}$ defined as follows:

$k_{e x o}^{B}=k_{2} \times\left[{ }^{1} \mathrm{O}_{2}\right]_{s s, \text { bulk,mod }}$

where $k_{2}$ is an apparent second-order rate constant for the reaction between ${ }^{1} \mathrm{O}_{2}$ and enterococcal isolates, and $\left[{ }^{1} \mathrm{O}_{2}\right]_{s s, b u l k, m o d}$ is the modeled steady-state concentration of singlet oxygen in wetland water in the field. The $k_{2}$ values were calculated from the measured $\left[{ }^{1} \mathrm{O}_{2}\right]_{s s, b u l k}$ and $k_{o b s}^{L}$ values in experiments in clear water and in wetland water under full spectrum simulated sunlight. It should be noted that $k_{2}$ values would likely vary in other water matrices that have different characteristics (e.g., different association between sensitizers and bacterial cells, different relative contributions of reactive intermediates). More details of calculations of $k_{2}$ and $\left[{ }^{1} \mathrm{O}_{2}\right]_{\text {ss,bulk,mod }}$ are presented in SI and Table S3.

\subsubsection{Calculating the ratio of modeled and measured inactivation rates, $r$}

To account for differences between lab and wetland conditions (e.g., susceptibility to sunlight inactivation of lab-cultured FIB vs. indigenous FIB, diurnal fluctuation of $\mathrm{pH}$ and $\mathrm{DO}$ ), we calculated the ratio of modeled and measured inactivation rates in in-situ batch reactors in the field $\left(r=k_{t o t}^{B} / k_{o b s}^{B}\right)$ and used $r$ as a correction factor for the prediction of inactivation rates in the pilot-scale 
wetland. $k_{o b s}^{B}$ values were measured from in-situ batch experiments, as described above. $k_{\text {tot }}^{B}$ values are the modeled values, calculated as the sum of $k_{\text {endo }}^{B}, k_{\text {exo }}^{B}$, and $k_{\text {dark }}^{B}$ using Equations (1)-(3). The $r$ values were calculated using $k^{B}$ instead of $k^{W}$ to avoid the possible influence of unknown factors (e.g., hydraulic shortcircuiting, varying FIB concentrations in the influent).

\subsubsection{Calculating $k_{\text {endo }}^{W}$ and $k_{\text {exo }}^{W}$}

Sunlight inactivation rates of indigenous $E$. coli and enterococci in the wetland were calculated using Equations (2) and (3), and corrected for the difference between lab and wetland conditions using their respective $r$ values:

$k_{\text {endo }}^{W}=\frac{1}{r} \times 24 \times k_{\text {endo }}^{L} \times \frac{\sum_{\lambda=280}^{400}\left\langle E_{0}^{\operatorname{sun}}(z, \lambda)\right\rangle_{z}}{\sum_{\lambda=280}^{400}\left\langle E_{0}^{\operatorname{sim}}(z, \lambda)\right\rangle_{z}}$

$k_{e x o}^{W}=\frac{1}{r} \times k_{2} \times\left[{ }^{1} \mathrm{O}_{2}\right]_{s s, \text { bulk,mod }}$

\subsection{Comparison of modeled and measured inactivation (task 6)}

The observed first-order inactivation rates of FIB in the pilotscale open-water wetland $\left(k_{o b s}^{W}\right)$ were determined from the monitoring data using the same approach described in our previous paper (Silverman et al., 2015). Briefly, $k_{o b s}^{W}$ values were calculated from monitoring data using the Wehner-Wilhelm equation, which describes a system with non-ideal flow and first-order kinetics (Wehner and Wilhelm, 1956).

$$
\left[\frac{C_{x}}{C_{0}}\right]^{W}=\frac{4 a \exp \left(\frac{1}{2 d}\right)}{(1+a)^{2} \exp \left(\frac{a}{2 d}\right)-(1-a)^{2} \exp \left(-\frac{a}{2 d}\right)}
$$

where $a=\sqrt{1+4 k_{o b s}^{W} \cdot \theta_{x} \cdot d} ; C_{x}$ and $C_{0}$ are the bacteria concentrations at each sampling location $(x)$ and at the inlet, respectively, $d$ is the dispersion number, and $\theta_{x}$ is the mean hydraulic retention time for each sampling location. $C_{x}$ and $C_{0}$ values are the monitoring data measured on a particular day. Values of $d$ and total $\theta_{x}$ were determined to be 0.08 and $1.12 \mathrm{~d}$, respectively (Silverman et al., 2015), based on the Rhodamine-WT tracer test (tracer test recovery was 77\%) (Jasper et al., 2014a). It was assumed that $\theta_{x}$ values at sampling locations turns 1,2 , and 3 correspond to $1 / 3,1 / 2$, and $2 / 3$ of total $\theta_{x}$, respectively. Values of $k_{o b s}^{W}$ were solved from Equation (6) using Solver (Microsoft Excel) by minimizing the root-mean-square error between $C_{x} / C_{0}$ values calculated from Equation (6) and observed $C_{x} /$ $C_{0}$ values of FIB throughout the year. The modeled values, $k_{\text {mod }}^{W}$, were calculated as the sum of $k_{\text {endo }}^{W}, k_{\text {exo }}^{W}$, and $k_{d a r k}^{B}$ using Equations (1), (4) and (5), and then compared with the observed values, $k_{o b s}^{W}$.

\subsection{Statistical tests}

GraphPad Prism 6.0.1 (GraphPad Software, La Jolla, CA) was used to perform all statistical tests. Comparison of inactivation rate constants was performed using two-way ANOVA or paired t-tests, depending on the number of variables examined.

\section{Results}

\subsection{Removal of the FIB in the open-water wetland}

The removal of $E$. coli from the inlet to the outlet in the openwater wetland $\left[-\log \left(C_{\text {out }} / C_{0}\right)\right.$, where $C_{\text {out }}$ and $C_{0}$ are concentrations of $E$. coli at the outlet and the inlet, respectively] generally increased with an increase in solar intensity, from $0.6 \mathrm{log}$ in December to about 3 logs in June and July (Fig. 1a). The lowest E. coli removal $(\sim 0.5 \mathrm{log})$ occurred when the water surface was covered completely by duckweed (i.e., the water had minimal exposure to sunlight), suggesting that sunlight inactivation was the main contributor to the removal of E. coli in the wetland. The removal under duckweed covered conditions was likely due to cell die-off, particle attachment-sedimentation, and predation processes (Kadlec and Wallace, 2009). From April to July, the removal of E. coli from the inlet to turn 1 ( 2 logs) was significantly higher than from turn 1 to the outlet (E. coli cells that are more susceptible to sunlight inactivation.

Similar to $E$. coli, the removal of enterococci was lowest ( $0.6 \mathrm{log})$ when duckweed covered the wetland, and increased when water was exposed to sunlight with the highest removal of 2.1 logs in April 2012 (Fig. 1b). Pigmentation tests revealed that the composition of enterococci in the wetland water included both pigmented and non-pigmented species (Fig. 2). The concentration of non-pigmented enterococci decreased significantly throughout the wetland, whereas there was no significant change in pigmented enterococci concentration, suggesting that the lower removal of enterococci compared to $E$. coli was due to the resistance of pigmented cells to sunlight inactivation.

\subsection{Inactivation of lab-cultured bacteria under simulated sunlight}

Lab experiments were conducted with clear water and wetland water under both full spectrum and UVB-blocked simulated sunlight to determine the kinetic parameters for endogenous and exogenous inactivation of lab-cultured bacteria. Under both light conditions, the inactivation of $E$. coli was lower in wetland water than in clear water before correcting for light screening (Fig. 3a), but was similar to clear water after correcting for light screening (Fig. 3b), indicating that exogenous mechanisms did not play an important role in the inactivation of $E$. coli in wetland water. The inactivation rates of $E$. coli in both clear water and wetland effluent water under full spectrum simulated sunlight were significantly higher than under UVB-blocked simulated sunlight (ANOVA, $\mathrm{p}<0.0001$ ), indicating the important role of UVB in endogenous inactivation.

The inactivation rates of all four lab-cultured enterococci were faster in wetland than in clear water (Fig. 3a). The difference was even greater after correcting for light screening (Fig. 3b), indicating that the lab-cultured enterococci were susceptible to exogenous inactivation in wetland water. The inactivation rates of two nonpigmented enterococci (Ent. faecalis and non-pigmented isolate) were higher than two pigmented enterococci (Ent. casseliflavus and pigmented isolate) under all conditions, indicating that the pigmented enterococci were more resistant to sunlight inactivation than the non-pigmented enterococci.

The $k_{\text {endo }}^{L}$ values (mean \pm one standard error) for $E$. coli, pigmented and non-pigmented enterococcal isolates were determined to be $3.97 \pm 0.35 \mathrm{~h}^{-1}, 1.04 \pm 0.07 \mathrm{~h}^{-1}$, and $1.72 \pm 0.16 \mathrm{~h}^{-1}$, respectively. The $k_{2}$ values for pigmented and non-pigmented enterococcal isolates were estimated to be $2.3 \times 10^{14} \mathrm{M}^{-1} \mathrm{~d}^{-1}$ and $4 \times 10^{14} \mathrm{M}^{-1} \mathrm{~d}^{-1}$, respectively. Inputs for the estimation of $k_{2}$ values include $k_{o b s}^{L}$ values of the pigmented and non-pigmented enterococcal isolates in wetland water $\left[1.04 \pm 0.07 \mathrm{~h}^{-1}\right.$ and 


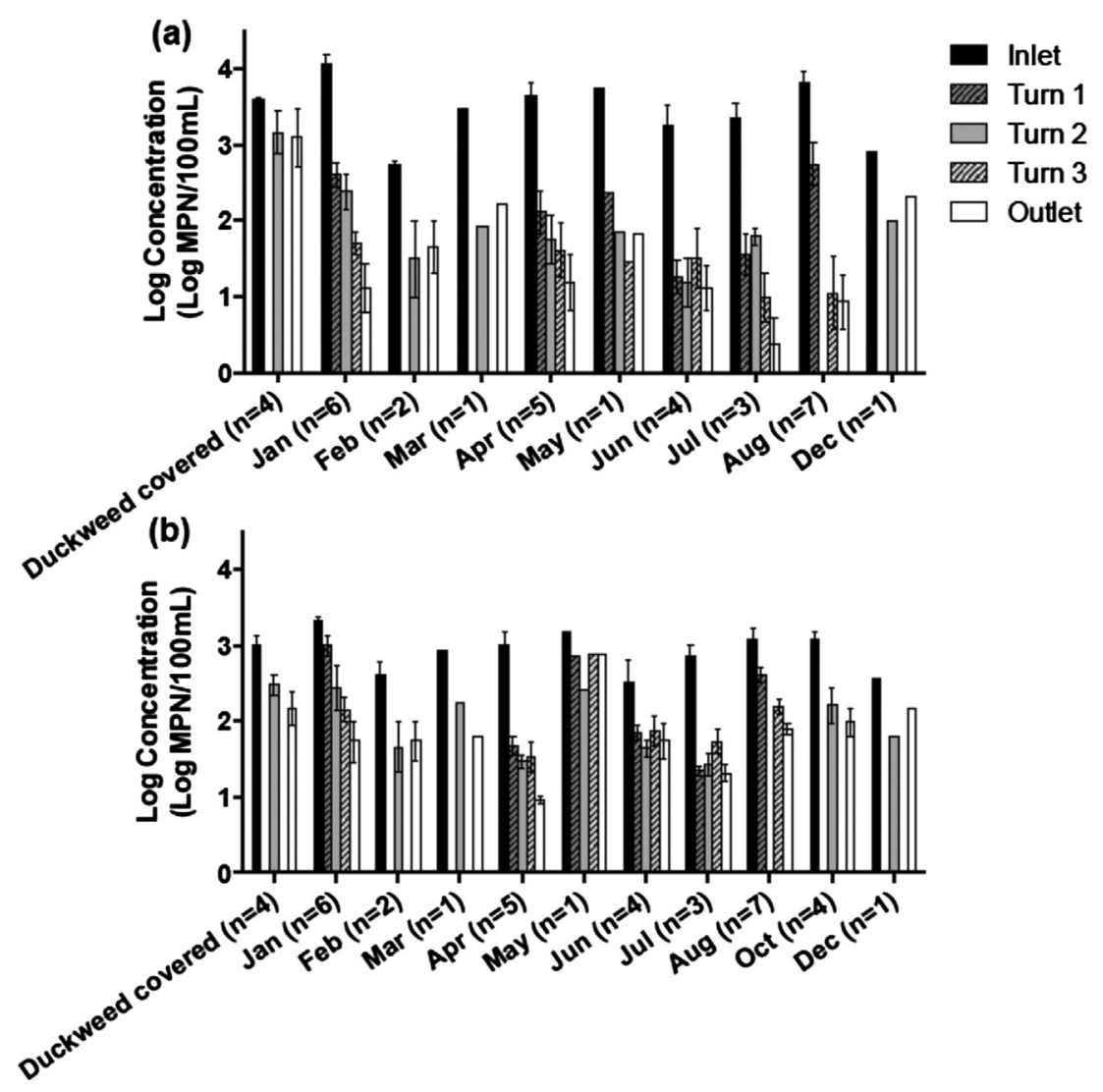

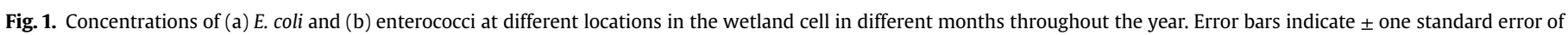

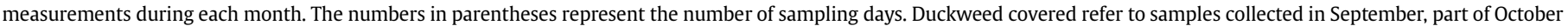
and November, when the wetland was completely covered with duckweed. Representative monthly 24-h averaged solar irradiance for each month is shown in Fig. S4.

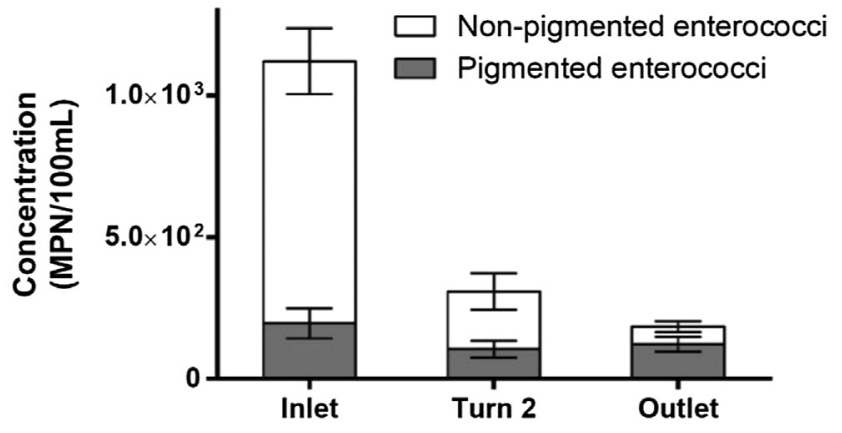

Fig. 2. Concentrations of pigmented and non-pigmented enterococci determined from pigmentation test results of samples collected from the inlet, turn 2, and outlet of the open-water wetland on 4 days in October 2012 when water exposed to sunlight. Error bars indicate \pm one standard error of replicate samples.

$2.35 \pm 0.27 \mathrm{~h}^{-1}$ ], their $k_{o b s}^{L}$ values in clear water $\left(=k_{\text {endo }}^{L}\right.$ values listed above), and the average steady-state singlet oxygen concentration in wetland water of $9.23 \times 10^{-14} \pm 9.56 \times 10^{-15} \mathrm{M}$ measured in experiments under full spectrum simulated sunlight (Table S3).

\subsection{Sunlight inactivation of lab-cultured FIB versus indigenous wastewater FIB}

\subsubsection{Lab results}

To test whether the susceptibility of lab-cultured FIB to sunlight inactivation was different than indigenous wastewater FIB, an experiment was conducted to measure inactivation rates of FIB from the two sources in clear water under full spectrum simulated sunlight (Fig. 4). Both $k_{o b s}^{L}$ and $k_{\text {photon.obs }}^{L}$ values showed that FIB cultured under lab conditions were more susceptible to endogenous inactivation than the indigenous wastewater FIB (t-test, $\mathrm{p}<0.05)$.

\subsubsection{In-situ batch reactors}

The inactivation rates of the FIB in batch reactors $\left(k_{t o t}^{B}\right)$ under field conditions were modeled using Equations (1)-(3), and compared with the measured values $\left(k_{o b s}^{B}\right)$. The $k_{t o t}^{B}$ values of all three indicators were generally higher than the $k_{o b s}^{B}$ values (Fig. 5). Details of $k_{o b s}^{B}$ and $k_{t o t}^{B}$ values are provided in Table S5. The ratio of modeled and measured inactivation rates in in-situ batch reactors $\left(r=k_{t o t}^{B} / k_{o b s}^{B}\right)$ of $E$. coli, and pigmented and non-pigmented enterococci are $1.77,12.81$, and 3.06 , respectively. To adjust for the differences between lab and field conditions (e.g., diurnal fluctuations in solar irradiance, $\mathrm{pH}$ and DO), we used the $r$ values as a correction factor.

\subsection{Modeling inactivation of the FIB in open-water wetland $\left(k_{t o t}^{W}\right.$ vs. $k_{o b s}^{W}$ )}

The best-fit inactivation rate constants, $k_{o b s}^{W}$, were calculated from the monitoring data using Equation (6) (Figs. S8-S10). In Fig. 6, these observed values are compared with the modeled inactivation rates of $E$. coli, and pigmented and non-pigmented 
enterococci in the wetland ( $k_{\text {tot }}^{W}$, determined from Equations (1), (4) and (5); the values of $k_{\text {endo }}^{W}$ and $k_{\text {exo }}^{W}$ are listed in Table S6) for each month. The monitoring data are highly variable and unexpectedly high in January, which was likely due to experimental errors (Fig. 6). Nevertheless, the $k_{\text {tot }}^{W}$ values are the same order of magnitude as the $k_{o b s}^{W}$ values, and generally follow the same trends. The model over-predicted $k_{o b s}^{W}$ values of pigmented enterococci for most months, and for non-pigmented enterococci from May to August by factors of $1.2-2.6$ indicating the model may not capture some factor(s) that inhibit sunlight inactivation. The model suggests that endogenous mechanisms were the main contributor to E. coli inactivation $(65 \%-87 \%$ of the total inactivation), while exogenous contributed slightly more than endogenous mechanisms to inactivation of pigmented and non-pigmented enterococci.

(a)

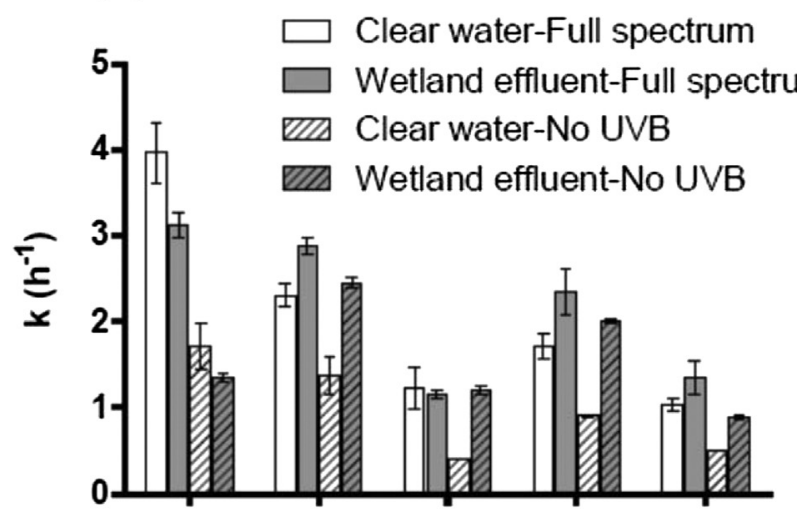

(b)

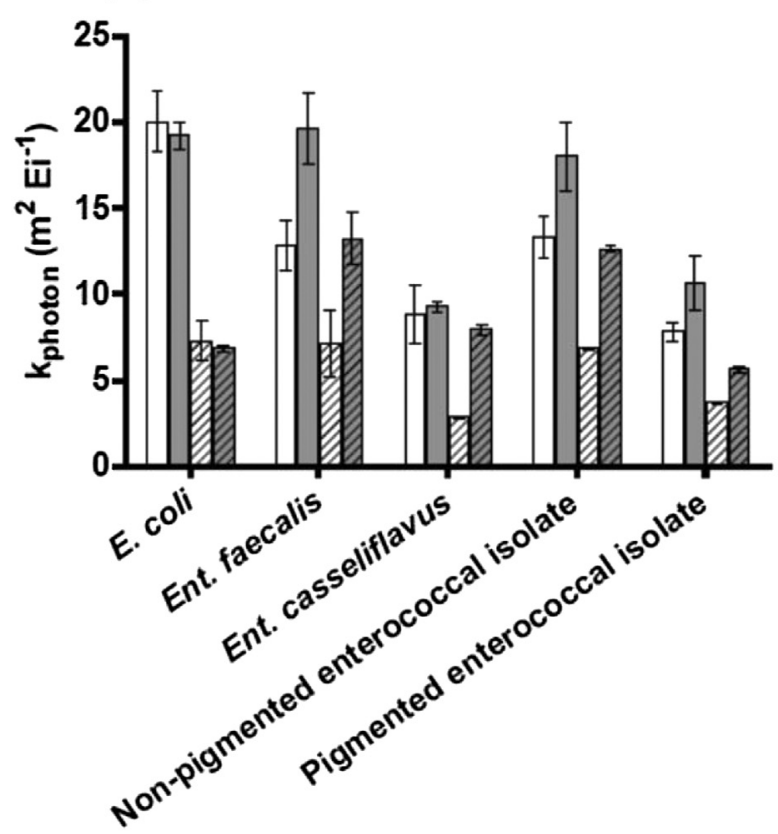

Fig. 3. Inactivation rate constants of lab-cultured E. coli, Ent. faecalis, Ent. casseliflavus, and field isolated non-pigmented and pigmented enterococci in clear water and wetland water under full spectrum and UVB-blocked simulated sunlight as (a) a function of time ( $k_{o b s}^{L}$, before correcting for light screening) or (b) a function of photon fluence ( $k_{o b s, p h o t o n}^{L}$, after correcting for light screening). Error bars indicate \pm one standard error of duplicate experiments.

\section{Discussion}

4.1. Contribution of endogenous and exogenous mechanisms to sunlight inactivation of lab-cultured bacteria under simulated sunlight

The susceptibility of all four lab-cultured enterococci (Ent. faecalis, Ent. casseliflavus, pigmented and non-pigmented enterococcal isolates), but not $E$. coli, to exogenous mechanisms is consistent with previous studies on sunlight inactivation of these bacteria in waste stabilization pond water (Davies-Colley et al., 1999; Kadir and Nelson, 2014). This study adds to the existing literature by demonstrating that both pigmented and non-pigmented enterococci strains are susceptible to exogenous inactivation, but that the pigmented strains are more resistant to exogenous inactivation than non-pigmented strains, which has been previously reported only for endogenous inactivation (Maraccini et al., 2011). The resistance of pigmented enterococci to both endogenous and exogenous sunlight inactivation is likely due to the presence of carotenoids, which are able to quench reactive intermediates, in the bacterial membrane of the yellow pigmented bacteria (Dahl et al., 1989).

\section{(a) E. coli}

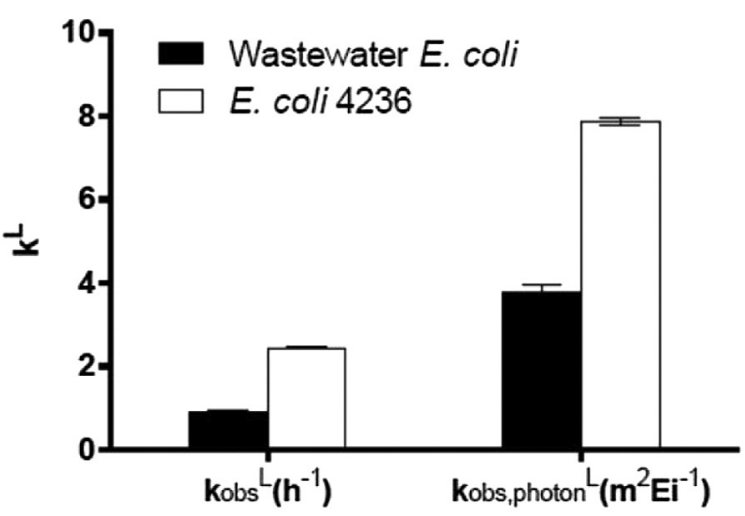

(b) Enterococci

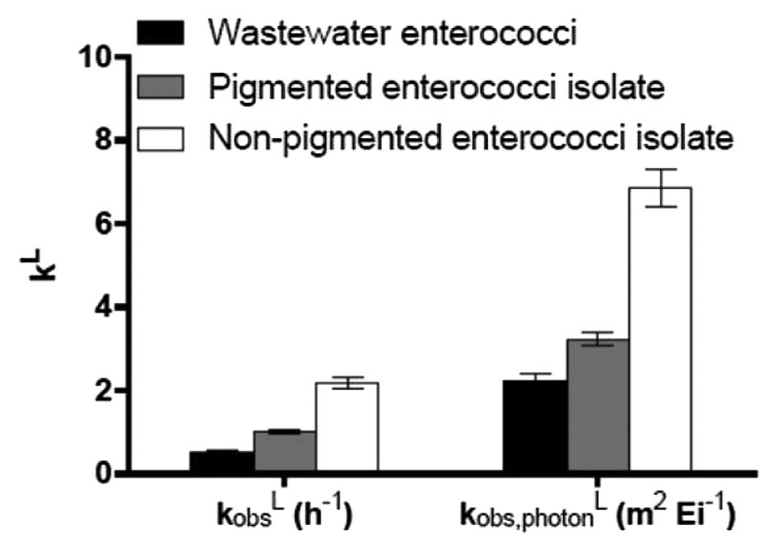

Fig. 4. Inactivation rate constants as functions of time ( $k_{o b s}^{L}$, before correcting for light screening) and as functions of photon fluence ( $k_{o b s \text {.photon }}^{L}$, after correcting for light screening) of indigenous wastewater FIB in comparison with lab-cultured FIB for (a) E. coli and (b) pigmented and non-pigmented enterococcal isolates in clear water under full spectrum simulated sunlight. Error bars indicate \pm one standard error of duplicate experiments. 
(a) E. coli

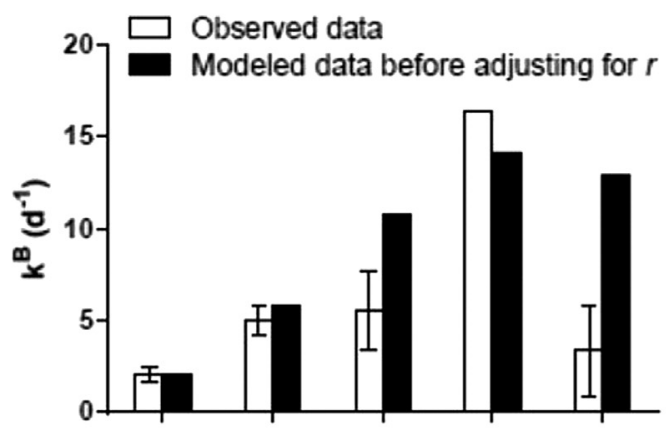

(b) Pigmented enterococci

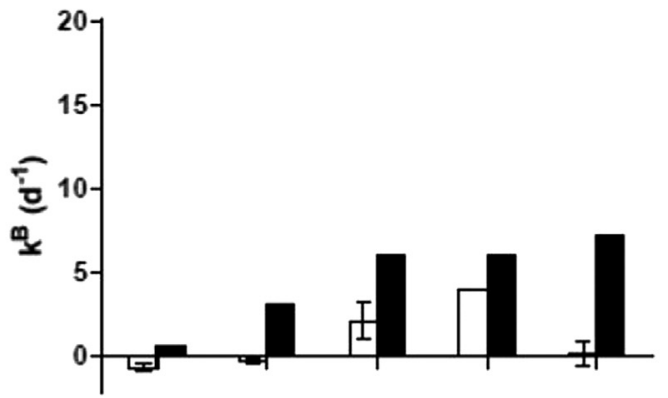

(c) Non-pigmented enterococci

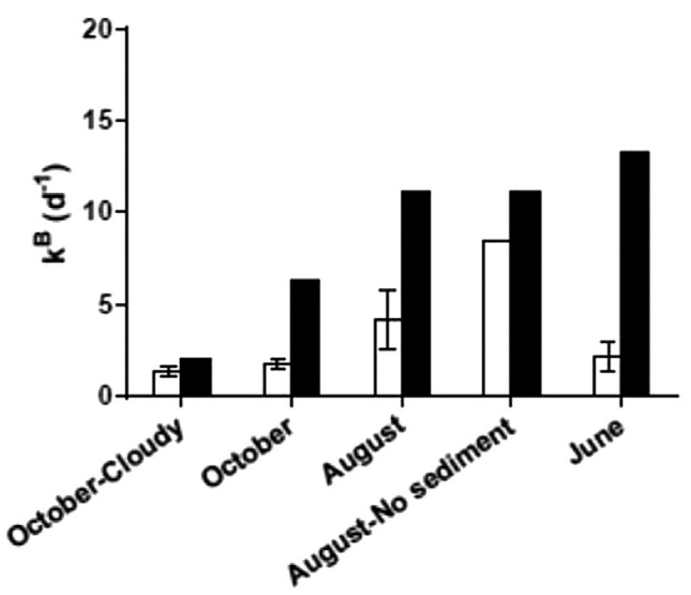

Fig. 5. Comparison between observed $\left(k_{o b s}^{B}\right)$ and modeled inactivation rate constants $\left(k_{\text {tot }}^{B}\right.$, before adjusting with the correction factor $r$ ) of (a) E. coli, (b) pigmented enterococci, and (c) non-pigmented enterococci in in-situ batch reactors. Error bars on the experimental data indicate \pm one standard error of duplicate experiments. No error bar was shown for experiment with single sample. Experiments were conducted at Discovery Bay, CA in August and October 2012, and June 2014.

The greater resistance of E. coli to exogenous mechanisms as compared to enterococci may be due to differences between the cellular membranes of Gram-negative bacteria (including E. coli) and Gram-positive bacteria (including enterococci). Gram-negative bacteria have an extra outer membrane (Valduga et al., 1993) that limits the uptake of exogenous photosensitizers into bacterial cells, reducing the ability of short-lived reactive intermediates (i.e., lifetimes of $n s-\mu s$ ) to damage Gram-negative cells (Nitzan and Pechatnikov, 2011). In addition, the cell walls of Gram-negative bacteria contain water and other reactive intermediate quenchers (a) E. coli

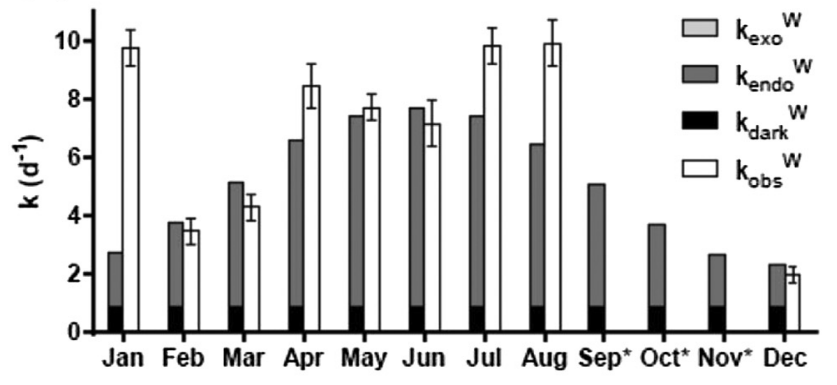

(b) Pigmented enterococci

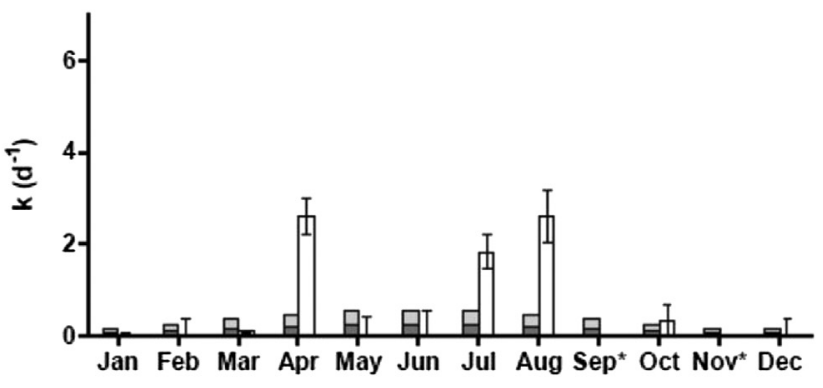

(c) Non-pigmented enterococci

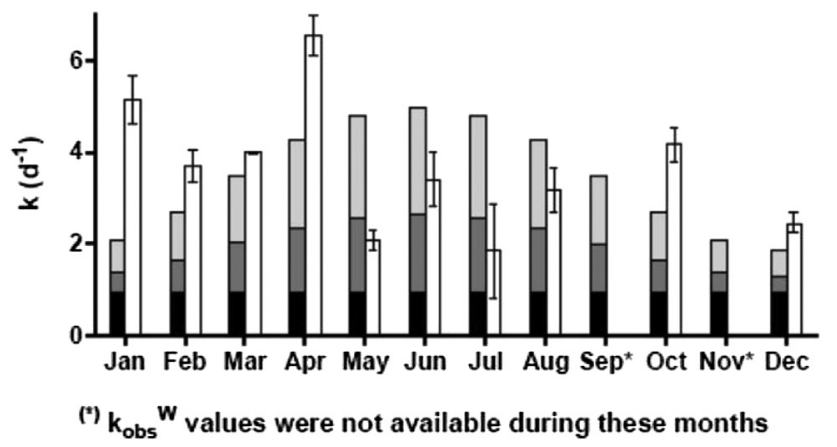

Fig. 6. Comparison between observed $\left(k_{o b s}^{W}\right)$ and modeled inactivation rate constants $\left(k_{t o t}^{W}\right.$, after adjusting with the correction factor $r$ ) of (a) $E$. coli, (b) pigmented enterococci, and (c) nonpigmented enterococci in the open-water wetland in different months of the year. $k_{o b s}^{W}$ values were not available in September, October and November for E. coli, and September and November for enterococci. Error bars on $k_{o b s}^{W}$ are root-mean-square errors.

which provide protection from exogenous reactive intermediates (Dahl et al., 1987).

\subsection{Lab-cultured bacteria as indicators for indigenous bacteria and pathogens in open-water wetlands receiving wastewater}

The greater susceptibility of lab-cultured FIB than indigenous wastewater FIB to sunlight inactivation is likely due in part to the differences in the growth conditions of the lab-cultured bacteria versus indigenous wastewater bacteria (Fisher et al., 2012). Specifically, the lab-cultured bacteria were grown on rich media under aerobic conditions, which could increase the biosynthesis of endogenous photosensitizers (Pedersen et al., 1978) and increase susceptibility of the bacteria to sunlight inactivation (Berney et al., 2006a). In contrast, the indigenous wastewater bacteria likely grew in anaerobic and iron-scarce conditions with lower specific growth rates (Fisher et al., 2012).

The difference between indigenous wastewater bacteria and 
lab-cultured bacteria also highlighted the challenges with using lab-cultured indicators to study inactivation of indigenous indicator microorganisms and human bacterial pathogens in wastewater. While research with lab-cultured indicator organisms provides valuable insight into the inactivation mechanisms, their inactivation rates in lab conditions cannot be directly used to estimate the inactivation rates of indigenous indicator organisms in the field. From this understanding and the field data, we propose using the correction factor $r$ as an adjustment for the discrepancy between inactivation rates of lab-cultured and indigenous organisms. It should be noted that the calculated $r$ values may be affected by the specific lab and field conditions in this study. Additional studies are needed to measure $r$ values for other conditions, to determine whether or not the values vary significantly. Further research is necessary to determine what differences may exist between the inactivation rates between lab FIB, field FIB, and actual human bacterial pathogens. A better understanding of inactivation mechanisms of human bacterial pathogens is also needed to provide insight into what factors influence the sunlight inactivation susceptibility of different species or serovars. For example, a limited number of studies on human pathogens has documented a difference in susceptibility to sunlight inactivation of lab-cultured E. coli and bacterial pathogens including Salmonella, Shigella, Vibrio cholerae, and Campylobacter (Berney et al., 2006a; Sinton et al., 2007). Even within the same species, there were differences in the sunlight inactivation rates of different Salmonella serovars (Boehm et al., 2012).

\subsection{Estimation of area necessary for inactivation of the FIB}

Typical concentrations of FIB in non-disinfected secondary effluents range from $10^{2}$ to $10^{5} \mathrm{MPN} / 100 \mathrm{~mL}$ (Bitton, 2010), such that a 3-log reduction would lower the concentrations below $100 \mathrm{MPN} /$ $100 \mathrm{~mL}$, which is below the requirement for $E$. coli concentration of the National Pollution Discharge Elimination System (NPDES) permit for discharges from wastewater treatment plants (i.e., no greater than $126 \mathrm{CFU} / 100 \mathrm{~mL}$ based on five samples taken over a 30-day period, nor any instantaneous reading exceed 406 CFU/ $100 \mathrm{~mL}$ ) (US EPA, 2004). Thus, for the purpose of assessing the land required for FIB treatment, the area needed to achieve 3-log removal of bacterial indicators from 1 MGD of wastewater

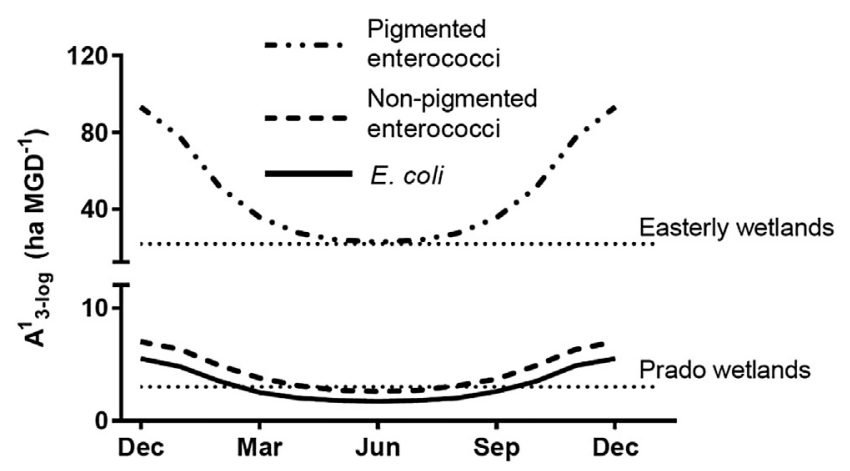

Fig. 7. Area predicted from model to provide 3-log removal (99.9\%) of E. coli, pigmented enterococci, and non-pigmented enterococci from 1 MGD of wastewater effluent in open-water treatment wetlands $\left(A_{3 l o g}^{1}\right)$ during different seasons. Characteristics of the wetlands: $[D O C]=8 \mathrm{mg} \mathrm{C} \mathrm{L}^{-1}$; depth $=20 \mathrm{~cm}$; daily averaged solar intensity under sunny, cloudless condition at $37^{\circ} 54^{\prime} \mathrm{N}$. Dashed lines show the area per MGD of existing full-scale wetland systems. Prado Wetlands (Orange County, California) receives water from Santa Ana River, yielding a footprint of about 3 ha MGD (Orange County Water District, 2008), and Easterly Wetlands (Orlando, Florida), with a footprint of about 22 ha MGD $^{-1}$ (Florida Department of Environmental Protection (2011)). effluent $\left(A_{3 \log }^{1}\right)$ was calculated based on an approach developed by Jasper and Sedlak (2013).

Predicted $A_{3 \log }^{1}$ values for E. coli and non-pigmented enterococci [5.5 ha and 7.0 ha per million gallons of wastewater effluent per day (MGD), respectively] are within the range of existing wetland system areas [i.e., 3 ha $\mathrm{MGD}^{-1}$ for Prado Wetlands (Orange County, California) and 22 ha $\mathrm{MGD}^{-1}$ Easterly Wetlands (Orlando, Florida)], indicating that open-water wetland cells of a practical size could provide efficient treatment for pathogens that share similar characteristics with these indicators throughout the year (Fig. 7). The high modeled values of $A_{3 \log }^{1}$ for pigmented enterococci are due to their resistance to sunlight inactivation; thus, total enterococci may be an overly conservative indicator for non-pigmented bacterial pathogens when removal is dominated by sunlight inactivation.

It should be noted that the actual $A_{3 \log }^{1}$ values might be higher than modeled values due to cloudy weather or the challenge of minimizing hydraulic short-circuiting in full-scale wetlands. Nonetheless, our modeled results show that open-water wetlands can play an important role in the multi-barrier approach to control the transmission of FIB and possibly waterborne pathogens.

\subsection{Comparison with high rate algal ponds}

Inactivation rates of $E$. coli derived from wetland field data are approximately three times higher than those reported for high rate algal ponds (HRAPs) with similar solar irradiation, depth, $\mathrm{pH}$, temperature, and DO $\left(2.9 \mathrm{~d}^{-1}\right.$ in winter and $7.0 \mathrm{~d}^{-1}$ in summer in this study as compared to $0.5 \mathrm{~d}^{-1}$ in winter and $1.9 \mathrm{~d}^{-1}$ in summer in HRAPs) (Craggs et al., 2004). The lower inactivation rates of $E$. coli in the HRAPs were likely because less UV light was able to penetrate the HRAP water column, which contains suspended algae, as compared to the open-water wetland $\left(a_{340 \mathrm{~nm}}^{W}=12 \mathrm{~m}^{-1}<a_{340 \mathrm{~nm}}^{\mathrm{HRAP}}=150 \mathrm{~m}^{-1}\right.$, where $a$ is absorption coefficient, and $340 \mathrm{~nm}$ was chosen as a representative wavelength in the UV range) (Craggs et al., 2004). Thus, open-water wetlands, which allow greater penetration of sunlight in the water column, appear to increase the inactivation rates of the FIB relative to other types of ponds. The $A_{3 \log }^{1}$ values were modeled for depths up to $100 \mathrm{~cm}$, and the required areas decreased with increasing depth for all three FIB, but with diminishing returns (Fig. S11). Given that minimal UV light penetrates deeper than $20 \mathrm{~cm}$ in the wetland water (Fig. S5), the decrease in required area is due to enhanced removal by dark processes with the longer hydraulic retention times, and to exogenous mechanisms for enterococci. The required areas decreased more for enterococci because we modeled ${ }^{1} \mathrm{O}_{2}$ production as a function of $410 \mathrm{~nm}$ light, which is attenuated less than the total UVB and UVA. However, it is possible that deeper wetlands may encourage the dominance of suspended algae instead of the biomat at the bottom, which would change the light attenuation.

\subsection{Modeling the inactivation of the FIB in the open-water wetland}

The sunlight inactivation rates derived from field data for pigmented and non-pigmented enterococci were highly variable, and they were difficult to predict with the model. A major source of uncertainty is likely the approach we used to calculate $k_{o b s}$ for pigmented and non-pigmented fractions of bacteria from the monitoring data. We determined the relative abundance of pigmented and non-pigmented strains in the in-situ reactors during two experiments and at each wetland location on four sampling dates in October. The relative abundance values were then applied to determine the concentrations (which were used to calculate $k_{o b s}$ ) for the other sampling dates. Thus, our $k_{o b s}$ values are inaccurate if changes occurred in the relative abundances of pigmented and 
non-pigmented strains. Additional research is needed to determine the magnitude of such changes in indigenous wastewater enterococci communities. The model confirmed the important contribution of exogenous mechanisms to inactivation of both pigmented and non-pigmented enterococci in the wetland. 16s rRNA sequencing of wetland isolates suggested species other than Enterococcus may be quantified using Enterolert, further complicating interpretation of the field-data derived inactivation rates. Future research to study factors influencing exogenous mechanisms, such as properties of photosensitizers in wetland water (i.e., their association with indicator bacteria and pathogens, spectroscopic characteristics, and production of reactive intermediates) is necessary. A better understanding of exogenous mechanisms can provide insight into how to optimize the design and operation of open-water wetlands to enhance sunlight inactivation.

A factor that likely contributed to the high variability in the inactivation rates of the monitoring data for all three FIB is that influent and effluent concentrations typically vary over time, due to changes in wastewater characteristics and treatment performance of upstream processes, and deposition of animal feces in the wetland (the culture-based enumeration methods cannot distinguish between human and animal sources of FIB). It is common for FIB concentrations to vary over several orders of magnitude over short time and spatial scales (Boehm et al., 2002). It is also likely that discrepancies between the model and the field-derived inactivation rates were caused by the simplified approach used to characterize the wetland hydraulics, because tracer data may not be sensitive enough to show the effects of short-circuiting on bacterial removal efficiency. Preferential flow paths, such as leaks through the wetland baffles, can cause water parcels to have different residence times in the wetland (Lightbody et al., 2008). If just $1 \%$ of the wetland water short-circuited through the wetland, an amount could not be observed with the Rhodamine tracer test used by Jasper et al. (2014a,b), the actual bacterial removal would be limited to $1 \log$ as compared to the modeled removal of 3 logs. These results emphasize the importance of good hydraulic design and minimizing short-circuiting in natural treatment systems used for disinfection (Jasper et al., 2013).

\section{Conclusions}

- Compared to vegetated wetlands and high rate algal ponds, open-water wetlands appear to provide higher removal rates of bacterial indicators, predominately through sunlight-mediated inactivation.

- Based on model results for the pilot-scale wetland, endogenous mechanisms were the main contributor to the inactivation of E. coli, and exogenous mechanisms contributed slightly more than endogenous mechanisms to the inactivation of four enterococci (Ent. faecalis, Ent. casseliflavus, pigmented, and nonpigmented enterococcal isolate), but did not contribute to E. coli removal.

- The existence of pigmented enterococci in non-disinfected secondary effluent increased the resistance of the total enterococci community to sunlight inactivation, suggesting that the non-pigmented Ent. faecalis, which is frequently used for laboratory research, is not a good indicator for sunlight inactivation of total enterococci. More research is needed to determine the prevalence of pigmentation in waterborne bacterial pathogens, which may have high resistance to sunlight inactivation.

- A novel experimental approach was used to compare sunlight inactivation rates determined from lab experiments to those of indigenous bacteria under field conditions, and a correction factor was introduced to the mechanistic model for predicting FIB removal in the open-water wetland.
- The mechanistic model is a useful tool for evaluating design parameters for open-water wetlands and can also be used for other sunlit water bodies.

\section{Acknowledgments}

This research was supported by the National Science Foundation (Grant CBET-0853568) and through the N.S.F. Engineering Research Center for Reinventing the Nations Urban Water Infrastructure (ReNUWIt) (EEC-1028968). We thank Dr. Ariel Grostern, Samantha Bear, Iris Schilling, and Dr. Andrea Silverman for help with labwork, fieldwork and useful discussions. We thank Dr. Alex Horne and Virgil Koehne for designing and managing the Discovery Bay treatment wetlands.

\section{Appendix A. Supplementary data}

Supplementary data related to this article can be found at http:// dx.doi.org/10.1016/j.watres.2015.06.043.

\section{References}

Berney, M., Weilenmann, H.-U., Ihssen, J., Bassin, C., Egli, T., 2006a. Specific growth rate determines the sensitivity of Escherichia coli to thermal, UVA, and solar disinfection. Appl. Environ. Microbiol. 72, 2586-2593. http://dx.doi.org/ 10.1128/AEM.72.4.2586-2593.2006.

Berney, M., Weilenmann, H.-U., Simonetti, A., Egli, T., 2006b. Efficacy of solar disinfection of Escherichia coli, Shigella flexneri, Salmonella Typhimurium and Vibrio cholerae. J. Appl. Microbiol. 101, 828-836. http://dx.doi.org/10.1111/ j.1365-2672.2006.02983.x.

Bitton, G., 2010. Wastewater Microbiology, Fourth edition.

Boehm, A.B., Grant, S.B., Kim, J.H., Mowbray, S.L., McGee, C.D., Clark, C.D., Foley, D.M., Wellman, D.E., 2002. Decadal and shorter period variability of surf zone water quality at Huntington Beach, California. Environ. Sci. Technol. 36, 3885-3892. http://dx.doi.org/10.1021/es020524u.

Boehm, A.B., Soetjipto, C., Wang, D., 2012. Solar inactivation of four Salmonella serovars in fresh and marine waters. J. Water Health 10, 504-510. http:// dx.doi.org/10.2166/wh.2012.084.

Boehm, A.B., Yamahara, K.M., Love, D.C., Peterson, B.M., McNeill, K., Nelson, K.L., 2009. Covariation and photoinactivation of traditional and novel indicator organisms and human viruses at a sewage-impacted Marine Beach. Environ. Sci. Technol. 43, 8046-8052. http://dx.doi.org/10.1021/es9015124.

Cooper, W.J., Zika, R.G., Petasne, R.G., Fischer, A.M., 1989. Sunlight-induced photochemistry of humic substances in natural waters: major reactive species. Water Res. 219, 333-362. http://dx.doi.org/10.1021/ba-1988-0219.

Craggs, R.J., Zwart, A., Nagels, J.W., Davies-Colley, R.J., 2004. Modelling sunlight disinfection in a high rate pond. Ecol. Eng. 22, 113-122. http://dx.doi.org/ 10.1016/j.ecoleng.2004.03.001.

Cunningham, M.L., Krinsky, N.I., Giovanazzi, S.M., Peak, M.J., 1985. Superoxide anion is generated from cellular metabolites by solar radiation and its components. J. Free Radicals Biol. Med. 1, 381-385. http://dx.doi.org/10.1016/0748-5514(85) 90150-3.

Dahl, T.A., Midden, W.R., Hartman, P.E., 1989. Comparison of killing of gramnegative and gram-positive bacteria by pure singlet oxygen. J. Bacteriol. 171, 2188-2194.

Dahl, T.A., Midden, W.R., Hartman, P.E., 1987. Pure singlet oxygen cytotoxicity for bacteria. Photochem. Photobiol. 46, 345-352.

Davies-Colley, R.J., Donnison, A.M., Speed, D.J., 1997. Sunlight wavelengths inactivating faecal indicator microorganisms in waste stabilisation ponds. Water Sci. Technol. 35, 219-225. http://dx.doi.org/10.1016/S0273-1223(97)00262-X.

Davies-Colley, R.J., Donnison, A.M., Speed, D.J., Ross, C.M., Nagels, J.W., 1999. Inactivation of faecal indicator micro-organisms in waste stabilisation ponds: interactions of environmental factors with sunlight. Water Res. 33, 1220-1230. http://dx.doi.org/10.1016/S0043-1354(98)00321-2.

Demographics of The Town of Discovery Bay, 2011. The Town of Discovery Bay [WWW Document]. http://www.townofdiscoverybay.org/content/ demographics/ (accessed 3.9.15).

Facklam, R.R., Collins, M.D., 1989. Identification of Enterococcus species isolated from human infections by a conventional test scheme. J. Clin. Microbiol. 27, $731-734$.

Fisher, M.B., Iriarte, M., Nelson, K.L., 2012. Solar water disinfection (SODIS) of Escherichia coli, Enterococcus spp., and MS2 coliphage: effects of additives and alternative container materials. Water Res. Oxf. 46.

Florida Department of Environmental Protection, 2011. Orlando Easterly Wetlands.

Fout, G.S., Dahling, D.R., Safferman, R.S., 2001. Concentration and processing of waterborne viruses by positive charge $1 \mathrm{MDS}$ cartridge filters and organic flocculation. In: USEPA Manual of Methods for Virology.

Gueymard, C.A., 2005. Interdisciplinary applications of a versatile spectral solar 
irradiance model: a review. Energy 30, 1551-1576. http://dx.doi.org/10.1016/ j.energy.2004.04.032.

Horne, A.J., Fleming-Singer, M., 2005. Phytoremediation Using Constructed Treatment Wetlands: an Overview. Bioremediation of Aquatic and Terrestrial Ecosystems, p. 329.

Jagger, J., 1985. Solar-uv Actions on Living Cells. Praeger.

Jasper, J.T., Jones, Z.L., Sharp, J.O., Sedlak, D.L., 2014a. Biotransformation of trace organic contaminants in open-water unit process treatment wetlands. Environ. Sci. Technol. 48, 5136-5144. http://dx.doi.org/10.1021/es500351e.

Jasper, J.T., Jones, Z.L., Sharp, J.O., Sedlak, D.L., 2014b. Nitrate removal in shallow, open-water treatment wetlands. Environ. Sci. Technol. 48, 11512-11520. http:// dx.doi.org/10.1021/es502785t.

Jasper, J.T., Nguyen, M.T., Jones, Z.L., Ismail, N.S., Sedlak, D.L., Sharp, J.O., Luthy, R.G., Horne, A.J., Nelson, K.L., 2013. Unit process wetlands for removal of trace organic contaminants and pathogens from municipal wastewater effluents. Environ. Eng. Sci. 30, 421-436. http://dx.doi.org/10.1089/ees.2012.0239.

Jasper, J.T., Sedlak, D.L., 2013. Phototransformation of wastewater-derived trace organic contaminants in open-water unit process treatment wetlands. Environ. Sci. Technol. 47 (19), 10781-10790.

Kadir, K., Nelson, K.L., 2014. Sunlight mediated inactivation mechanisms of Enterococcus faecalis and Escherichia coli in clear water versus waste stabilization pond water. Water Res. 50, 307-317. http://dx.doi.org/10.1016/ j.watres.2013.10.046.

Kadlec, R.H., Wallace, S., 2009. Treatment Wetlands. CRC Press.

Kohn, T., Nelson, K.L., 2007. Sunlight-mediated inactivation of MS2 coliphage via exogenous singlet oxygen produced by sensitizers in natural waters. Environ. Sci. Technol. 41, 192-197.

Lightbody, A.F., Avener, M.E., Nepf, H.M., 2008. Observations of short-circuiting flow paths within a free-surface wetland in Augusta, Georgia, U.S.A. Limnol. Oceanogr. 53, 1040-1053. http://dx.doi.org/10.4319/lo.2008.53.3.1040.

Maraccini, P.A., Ferguson, D.M., Boehm, A.B., 2011. Diurnal variation in Enterococcus species composition in polluted ocean water: a potential role for the enterococcal carotenoid in protection against photoinactivation. Appl. Environ. Microbiol. 78, 305-310. http://dx.doi.org/10.1128/AEM.06821-11.

Mattle, M.J., Vione, D., Kohn, T., 2015. Conceptual model and experimental framework to determine the contributions of direct and indirect photoreactions to the solar disinfection of MS2, phiX174, and adenovirus. Environ. Sci. Technol. 49, 334-342. http://dx.doi.org/10.1021/es504764u.

McGuigan, K.G., Conroy, R.M., Mosler, H.-J., du Preez, M., Ubomba-Jaswa, E.,
Fernandez-Ibañez, P., 2012. Solar water disinfection (SODIS): a review from bench-top to roof-top. J. Hazard. Mater. 235-236, 29-46. http://dx.doi.org/ 10.1016/j.jhazmat.2012.07.053.

Nguyen, M.T., Silverman, A.I., Nelson, K.L., 2014. Sunlight inactivation of MS2 coliphage in the absence of photosensitizers: modeling the endogenous inactivation rate using a photoaction spectrum. Environ. Sci. Technol. 48, 3891-3898. http://dx.doi.org/10.1021/es405323p.

Nitzan, Y., Pechatnikov, I., 2011. Chapter 3. Approaches to kill gram-negative bacteria by photosensitized processes. In: Hamblin, M.R., Jori, G. (Eds.), Comprehensive Series in Photochemical \& Photobiological Sciences. Royal Society of Chemistry, Cambridge, pp. 45-67.

Orange County Water District, 2008. Prado Wetlands.

Pedersen, S., Bloch, P.L., Reeh, S., Neidhardt, F.C., 1978. Patterns of protein synthesis in E. coli: a catalog of the amount of 140 individual proteins at different growth rates. Cell 14, 179-190.

Silverman, A.I., Nguyen, M.T., Schilling, I.E., Wenk, J., Nelson, K.L., 2015. Sunlight inactivation of viruses in open-water unit process treatment wetlands: modeling endogenous and exogenous inactivation rates. Environ. Sci. Technol. 49 (5), 2757-2766. http://dx.doi.org/10.1021/es5049754.

Silverman, A.I., Peterson, B.M., Boehm, A.B., McNeill, K., Nelson, K.L., 2013. Sunlight inactivation of human viruses and bacteriophages in coastal waters containing natural photosensitizers. Environ. Sci. Technol. 47, 1870-1878. http:/| dx.doi.org/10.1021/es3036913.

Sinton, L., Hall, C., Braithwaite, R., 2007. Sunlight inactivation of Campylobacter jejuni and Salmonella enterica, compared with Escherichia coli, in seawater and river water. J. Water Health 5, 357. http://dx.doi.org/10.2166/wh.2007.031.

Sinton, L.W., Hall, C.H., Lynch, P.A., Davies-Colley, R.J., 2002. Sunlight inactivation of fecal indicator bacteria and bacteriophages from waste stabilization pond effluent in fresh and saline waters. Appl. Environ. Microbiol. 68, 1122-1131. http://dx.doi.org/10.1128/AEM.68.3.1122-1131.2002.

US EPA, R. 9, 2004. NPDES Wastewater \& Stormwater Permits - Water. US EPA Pacific Southwest [WWW Document]. http://www.epa.gov/region9/water/ npdes/index.html (accessed 9.28.14).

Valduga, G., Bertoloni, G., Reddi, E., Jori, G., 1993. Effect of extracellularly generated singlet oxygen on gram-positive and gram-negative bacteria. J. Photochem. Photobiol. B, Biol. 21, 81-86.

Wehner, J.F., Wilhelm, R.H., 1956. Boundary conditions of flow reactor. Chem. Eng. Sci. 6, 89-93. http://dx.doi.org/10.1016/0009-2509(56)80014-6. 